\title{
Insertion sequence ISEcp1-like element connected with a novel aph(2") allele [aph(2")-le] conferring high-level gentamicin resistance and a novel streptomycin adenylyltransferase gene in Enterococcus
}

\begin{abstract}
Correspondence
Yun-Song Yu

yvys119@163.com
\end{abstract}

Received 28 April 2006

Accepted 26 July 2006

\author{
Ya-Gang Chen, Ting-Ting Ou, Yun-Song Yu, Jian-Ying Zhou \\ and Lan-Juan Li
}

\begin{abstract}
Infectious Disease Department, The First Affiliated Hospital, Medical School, Zhejiang University, The Key Laboratory of Infectious Diseases of Public Health Ministry, Zhejiang, Hangzhou, China
\end{abstract}

Enterococcus casseliflavus $\mathrm{HZ95}$ is an enterococcus with high-level resistance to aminoglycosides. Nine genes responsible for high-level aminoglycoside resistance, including aac $\left(6^{\prime}\right)-l e-$

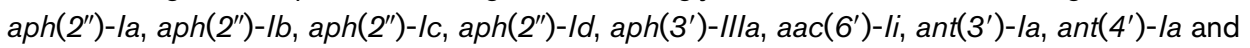
ant $\left(6^{\prime}\right)$-la, were not detected in HZ95. An 8 kb fragment from unconjugative plasmids of HZ95 was cloned, and expressed gentamicin resistance in Escherichia coli $\mathrm{DH} 5 \alpha$. The genetic structures ( $8 \mathrm{~kb}$ DNA fragment) containing these aminoglycoside-modifying enzyme genes in Ent. casseliflavus $\mathrm{HZ95}$ were determined. The deduced amino acid sequence of the novel aph(2") allele, aph(2")-le, had 93.7\% amino acid identity with $\mathrm{APH}\left(2^{\prime \prime}\right)$-ld. The aph(2")-le gene was bracketed upstream by an insertion sequence (IS)Ecp1-like element and downstream by a streptomycin adenylyltransferase gene (str). The streptomycin adenylyltransferase encoded by the str gene had $80.3 \%$ amino acid identity with the protein encoded by aadE. The plasmid of $\sim 16 \mathrm{~kb}$ could hybridize with a PCR-generated aph(2")-le intragenic probe. The ISEcp1-like element had $91 \%$ identity with ISEcp1. ISEcp1, which commonly acts as a key factor in the dissemination of CTX-Mtype $\beta$-lactamase genes in Gram-negative bacteria, has not been reported in Enterococcus.

\section{INTRODUCTION}

The incidence of nosocomial enterococcal infections has increased, and enterococci have become one of the most common nosocomial pathogens (Schaberg et al., 1991; Murray, 1998). Optimal therapy of serious enterococcal infections usually involves a synergistic combination of an agent that interferes with cell wall biosynthesis, such as ampicillin, and an aminoglycoside. Gentamicin has been the preferred aminoglycoside; however, the increasing prevalence of high-level gentamicin resistance (HLGR) (as high as $52.6 \%$ in China) (Wang et al., 1999), which eliminates this synergistic bactericidal effect, has compromised the effectiveness of therapy. The aac $\left(6^{\prime}\right)-I e-a p h\left(2^{\prime \prime}\right)-I a$ gene is responsible for the HLGR of strains by encoding $\mathrm{AAC}\left(6^{\prime}\right)-\mathrm{Ie}-\mathrm{APH}\left(2^{\prime \prime}\right)-\mathrm{Ia}$, a gentamicin-modifying enzyme

Abbreviations: AME, aminoglycoside-modifing enzyme; HLGR, highlevel gentamicin resistance; IS, insertion sequence.

The GenBank/EMBL/DDBJ accession number for the cloned fragment sequence of Ent. casseliflavus HZ95 containing the novel HLGR gene $\operatorname{aph}\left(2^{\prime \prime}\right)-l e$ is AY939911.
(Ferretti et al., 1986). This gene for a bifunctional enzyme confers resistance to essentially all clinically available aminoglycosides, except streptomycin, and eliminates the synergism between aminoglycosides and cell-wall-active agents. Three novel genes encoding phosphotransferases, including $\mathrm{APH}\left(2^{\prime \prime}\right)$-Ic, $\mathrm{APH}\left(2^{\prime \prime}\right)$-Id and $\mathrm{APH}\left(2^{\prime \prime}\right)-\mathrm{Ib}$, have been detected (Chow et al., 1997; Tai et al., 1998; Kao et al., 2000). The detection of resistance genes is employed to predict bactericidal synergism in enterococci.

Resistance to streptomycin can be mediated by ribosomal mutation or by the enzymic modification of the drug. Ribosomal resistance is usually associated with streptomycin MICs $>32000 \mu \mathrm{g} \mathrm{ml}^{-1}$, while enzyme-mediated resistance produces lower MICs (Eliopoulos et al., 1984). The aadE gene (also refered to as the $6^{\prime}$-ant gene) is the main streptomycin adenylyltransferase gene detected in Enterococcus (Werner et al., 2001; Derbise et al., 1997). The aadA gene (also referred to as the $3^{\prime \prime}$-ant gene) has also been reported in Gram-negative organisms and Staphylococcus aureus, but has not been reported in Enterococcus (Ahmed \& Shimamoto, 2004; Clark et al., 1999). 
Insertion sequences (ISs) are an important source of genetic plasticity in prokaryotes. Tn5281 is often associated with the dissemination of the $a a c\left(6^{\prime}\right)-I e-a p h\left(2^{\prime \prime}\right)$-Ia gene with IS256 upstream and reverse IS256 downstream in HLGR strains (Simjee et al., 1999; Hallgren et al., 2003). In contrast, ISEcp1 is often reported to be involved in the mobilization of resistance genes, such as CTX-M in Gram-negative bacteria, but has not been reported in Gram-positive bacteria (Poirel et al., 2005; Cao et al., 2002). The aadA gene located in a class 1 integron has also been reported in Enterococcus faecalis (Clark et al., 1999).

The genetic environment of a novel $a p h\left(2^{\prime \prime}\right)$ allele $\left[a p h\left(2^{\prime \prime}\right)\right.$ Ie] conferring HLGR was investigated, and the surrounding sequences that included the streptomycin adenylyltransferase gene (str) and an ISEcp1-like element were described.

\section{METHODS}

Bacterial strains, plasmids, and susceptibility testing. The Enterococcus casseliflavus strain used in this study (HZ95) was originally isolated from the ascites of a patient at the intensive care unit (ICU) of a teaching hospital in China. The strain was identified to the species level by the API 20 Strep system and Vitek GPI (bioMérieux) for Gram-positive organisms, and was confirmed to have the vanC2 gene by PCR amplification. Strains and plasmids used in this study are shown in Table 1 . One hundred and two clinical enterococci (44 Enterococcus faecium isolates, 48 Ent. faecalis isolates, six Enterococcus gallinarum isolates, three Ent. casseliflavus isolates and one Enterococcus avium isolate) from unrelated patients in the hospital were used to screen for HLGR and the novel aminoglycoside-resistance genes. Staph. aureus ATCC 25923 and Ent. faecalis ATCC 29212 were used as the reference strains for quality control. MICs of seven aminoglycosides, gentamicin, netilmicin, tobramicin, kanamycin, amikacin, isepamicin and streptomycin, to Escherichia coli pT95 and E. coli pGEM-T Easy were determined by the agar dilution method. MICs of these seven aminoglycosides, ampicillin, vancomycin, teicoplanin and linezolid were also performed for the Ent. casseliflavus HZ95 strain. Interpretation of the results was according to Clinical and Laboratory Standards Institute [CLSI; formerly the National Committee for Clinical Laboratory Standards (NCCLS)] 2005 guidelines (CLSI, 2005).

Screening for strains displaying HLGR. HLGR (MIC $>500 \mu \mathrm{g} \mathrm{ml}^{-1}$ ) was confirmed by an agar screening method according to CLSI (2005). The isolate was dotted at $10^{6}$ c.f.u. on brain heart infusion (BHI) plates containing gentamicin $\left(500 \mu \mathrm{g} \mathrm{ml}^{-1}\right)$, and was incubated at $35^{\circ} \mathrm{C}$ for $24 \mathrm{~h}$. Growth of more than one colony was determined to be the best indicator of HLGR.
Detection of aminoglycoside-resistance genes by PCR. The presence of the genes for the aminoglycoside-modifying enzymes (AMEs) responsible for high-level aminoglycoside resistance was confirmed by PCR. The studied genes were aac $\left(6^{\prime}\right)-I e-a p h\left(2^{\prime \prime}\right)-I a$, $\operatorname{aph}\left(2^{\prime \prime}\right)-I b, \operatorname{aph}\left(2^{\prime \prime}\right)-I c, \operatorname{aph}\left(2^{\prime \prime}\right)-I d, \operatorname{aph}\left(3^{\prime}\right)-I I I a, a a c\left(6^{\prime}\right)-I i, \operatorname{ant}\left(3^{\prime}\right)-$ $I a$, ant $\left(4^{\prime}\right)-I a$ and $\operatorname{ant}\left(6^{\prime}\right)-I a$. PCR reactions were done on bacterial lysates. PCR assays were performed to amplify these genes as described previously (Donabedian et al., 2003). Strains that were positive for $\operatorname{aac}\left(6^{\prime}\right)-I e-a p h\left(2^{\prime \prime}\right)-I a, a p h\left(2^{\prime \prime}\right)-I b, a p h\left(2^{\prime \prime}\right)-I c, a p h\left(2^{\prime \prime}\right)-I d$, aph $\left(3^{\prime}\right)-I I I a$, aac $\left(6^{\prime}\right)-I i$, ant $\left(3^{\prime}\right)-I a$, ant $\left(4^{\prime}\right)-I a$ and $\operatorname{ant}\left(6^{\prime}\right)-I a$ in our laboratory were employed as positive controls, and Ent. faecalis ATCC 29212 was used as a negative control. We confirmed all positive results by sequencing the PCR product, for which Ent. faecalis ATCC 29212 was again used as a negative control strain.

Purification, cloning and sequencing of PCR products. PCR products were purified by using the 35 Spin PCR Product Purification kit (Shenergy Biocolor). Cloning was done by standard methods, using the purified PCR products, the pGEM-T Easy vector and E. coli DH $5 \alpha$. The PCR products were sequenced by the dideoxynucleotide chain-termination method on an ABI 377 sequencer. Sequence analysis employed BLAST from the National Center for Biotechnology Information (NCBI). DNAssit version 2.2 software was used to compare similarities among other sequences.

Conjugative experiments. Conjugation experiments were carried out using a broth mating technique between the clinical isolate Ent. casseliflavus HZ95 (displays HLGR and is susceptible to rifampicin and fusidic acid) and Ent. faecalis JH2-2 (fusidic acid and rifampicin resistant and gentamicin susceptible) or Ent. faecium BM4105RF (rifampicin resistant and gentamicin susceptible), as previously described, with a donor/recipient ratio of $1: 2$. The mating time of broth mating was $4 \mathrm{~h}$ (Ike et al., 1998). Portions of the mixed cultures were then transferred to plates of solid media with appropriate selective antibiotics. Colonies were counted after $48 \mathrm{~h}$ incubation at $37^{\circ} \mathrm{C}$.

Plasmid isolation, preparation of probe, and Southern blot hybridization. A Qiagen Plasmid Midi kit was used to extract plasmids in HZ95. Plasmids were digested with the restriction enzyme HindIII. After agarose gel electrophoresis, DNA fragments in the gel were transferred to a nylon membrane. The DNA fragment of the aph $\left(2^{\prime \prime}\right)$-Id gene in the strain HZ95 obtained by PCR amplification (Tai et al., 1998) was purified as described above. The purified fragment $\left(642 \mathrm{bp}\right.$ ) was labelled with the Prime-H-Gene ${ }^{33} \mathrm{P}$ probe labelling kit (Promega) for use as a DNA probe.

Cloning of the plasmid-encoded gentamicin-modifying enzyme gene. Plasmid DNA was extracted from HZ95 by the Qiagen Plasmid Midi kit and digested with HindIII. Purified digested product, $3.5 \mathrm{mmol} \mathrm{Mg}^{2+} \mathrm{l}^{-1}, 200 \mu \mathrm{mol} \mathrm{dNTPs} 1^{-1}$ and 1.6 U Taq polymerase were added to $1 \times$ PCR buffer. The mixture was extended in a PCR amplifier (ThermoHybaid) at $72{ }^{\circ} \mathrm{C}$ for

Table 1. Reference strains and plasmids used in this study

\begin{tabular}{|llc|}
\hline Strain or plasmid & \multicolumn{1}{c|}{ Characteristics } & Source or reference \\
\hline $\begin{array}{l}\text { Strains } \\
\text { E. coli pGEM-T Easy }\end{array}$ & E. coli DH5 $\alpha$ harbouring pGEM-T Easy vector & This study \\
$\begin{array}{l}\text { E. coli pT95 } \\
\text { Plasmids }\end{array}$ & Transformant, E. coli DH5 $\alpha$ harbouring pT95 & This study \\
pGEM-T Easy & Ampicillin resistant, empty vector & Promega \\
PT95 & Recombinant pGEM-T Easy plasmid with an 8724 bp & This study \\
& HindIII fragment containing $a p h\left(2^{\prime \prime}\right)-I e$ insert & \\
\hline
\end{tabular}


$8724 \mathrm{bp}$

Fig. 1. The cloned Ent. casseliflavus frag-
ment of four ORFs, 8724 bp in total. The
fragment was cloned from plasmids of HZ95
digested by Hindlll. The arrows indicate the
orientations of the ORFs.

$30 \mathrm{~min}$. The cohesive terminal was repaired and adenosine deoxyriboside (A) was added to the terminal. Purified product $(3 \mu \mathrm{l})$ was linked with $1 \mu \mathrm{l}$ pGEM-T Easy vector. The linked product was transformed to E. coli $\mathrm{DH} 5 \alpha$ competent bacteria, and then the resultant bacteria were spread on a MacConkey plate containing $50 \mu \mathrm{g}$ ampicillin $\mathrm{ml}^{-1}$ and $8 \mu \mathrm{g}$ gentamicin $\mathrm{ml}^{-1}$. White colonies designating the E. coli pT95 clone were picked the following day. The plasmid was extracted and digested with EcoRI to check for insertions in the vector DNA. The purified transformant plasmid DNA from E. coli pT95 clones with an insert of the target DNA was used as the template for the walking sequencing reaction (Fig. 1). A similarity search of the sequence was carried out using the BLAST program available at the NCBI BLAST homepage (http://www.ncbi.nlm.nih.gov/blast/).

Identification of the aph(2")-le and str genes in enterococci. Novel primers (P1, 5'-GGATCCGTAGAGAAGACATGAC-3'; P2, $5^{\prime}$-CTCGAGCATTAGCAGTCC-3') were designed to amplify the whole sequence of the $a p h\left(2^{\prime \prime}\right)-I e$ gene, and additional primers (P3, 5'-CGCAGTTTCTGAATTTGCTTATC-3'; P4, 5'-CGCTTCTATATCCATTCATCTCA-3') were designed to amplify the str gene. PCR assays were performed to amplify the $a p h\left(2^{\prime \prime}\right)-I e$ and $s t r$ genes among the 102 clinical enterococci.

\section{RESULTS}

\section{Microbiological characterization}

Ent. casseliflavus HZ95 was high-level resistant to gentamicin, netilmicin, tobramicin, kanamycin, amikacin and isepamicin (MICs $>1024 \mu \mathrm{g} \mathrm{ml}^{-1}$ ), but was low-level resistant to streptomycin (MIC $=128 \mu \mathrm{g} \mathrm{ml}^{-1}$; Table 2). MICs of ampicillin, vancomycin, teicoplanin and linezolid for Ent. casseliflavus HZ95 were 256, 1, 1 and $2 \mu \mathrm{g} \mathrm{ml}^{-1}$, respectively. Among 102 clinical strains, 68 (66.7\%) isolates displaying HLGR were detected.

\section{Novel gentamicin-resistance gene, aph(2") allele [aph(2")-le], and its location}

A DNA fragment of 642 bp was obtained from total DNA of HZ95. The nucleotide sequence for the novel HGLR aph $\left(2^{\prime \prime}\right)$ allele $a p h\left(2^{\prime \prime}\right)-I e$ is available from GenBank under accession number AY677166. No positive PCR amplification result was seen in the isolate with specific primers for aminoglycoside-resistance genes, including $\operatorname{aac}\left(6^{\prime}\right)-I e-a p h\left(2^{\prime \prime}\right)-I a$, $\operatorname{aph}\left(2^{\prime \prime}\right)-I b, \operatorname{aph}\left(2^{\prime \prime}\right)-I c, a p h\left(2^{\prime \prime}\right)-I d, \operatorname{aph}\left(3^{\prime}\right)-I I I a, \operatorname{aac}\left(6^{\prime}\right)-I i$, $\operatorname{ant}\left(3^{\prime}\right)-I a$, ant $\left(4^{\prime}\right)-I a$ and $\operatorname{ant}\left(6^{\prime}\right)-I a$.

Southern-blot hybridization was used to determine the location of the aph $\left(2^{\prime \prime}\right)$-Ie gene in E. casseliflavus HZ95. Four kinds of plasmids were detected in Ent. casseliflavus HZ95, but positive hybridization signals were detected only in the $16 \mathrm{~kb}$ plasmid band and the $8.7 \mathrm{~kb}$ HindIII-digested fragment.

\section{Conjugation, cloning and expression of the gentamicin-resistance gene}

No transconjugants were selected by conjugation experiments. The plasmids from HZ95 digested by HindIII were ligated to the pGEM-T Easy vector. After transformation of the ligated products, the gentamicin-resistant transformants were selected. An E. coli $\mathrm{DH} 5 \alpha$ derivative resistant to gentamicin was obtained and named E. coli pT95, and contained an $8.7 \mathrm{~kb}$ cloned fragment. Aminoglycoside MICs for E. coli pT95 and E. coli pGEM-T Easy are shown in Table 2. Repeated attempts to electroporate the native $16 \mathrm{~kb}$ plasmid into Ent. faecalis $\mathrm{JH} 2-2$ failed.

Table 2. Susceptibilities of Ent. casseliflavus HZ95, E. coli pT95 and E. coli pGEM-T Easy to aminoglycosides

Values show MIC $\left(\mu \mathrm{g} \mathrm{ml}^{-1}\right)$.

\begin{tabular}{|lccc|}
\hline Aminoglycoside & \multicolumn{3}{c|}{ Strain } \\
\cline { 2 - 4 } & Ent. casseliflavus HZ95 & E. coli pT95 & E. coli pGEM-T Easy \\
\hline Gentamicin & $\geqslant 1024$ & 24 & $0 \cdot 125$ \\
Netilmicin & $\geqslant 1024$ & $8 \cdot 0$ & $0 \cdot 5$ \\
Tobramicin & $\geqslant 1024$ & $8 \cdot 0$ & $0 \cdot 25$ \\
Kanamycin & $\geqslant 1024$ & $8 \cdot 0$ & $0 \cdot 25$ \\
Amikacin & $\geqslant 1024$ & $1 \cdot 0$ & $1 \cdot 0$ \\
Isepamicin & $\geqslant 1024$ & $0 \cdot 25$ & $0 \cdot 125$ \\
Streptomycin & 128 & $2 \cdot 0$ & $1 \cdot 0$ \\
\hline
\end{tabular}




\section{Nucleotide sequencing of the cloned fragment}

The nucleotide sequence of the cloned fragment revealed the presence of four ORFs, 8724 bp in total (GenBank accession no. AY939911) (Fig. 1). The nucleotide and deduced amino acid sequences of these ORFs were compared with the sequences in the GenBank database by the BLAST program.

The first ORF (373-2029 bp) was an insertion sequence $91 \%$ identical to IsEcp1, and contained a transposase gene $(\operatorname{tnpA})(561-1823 \mathrm{bp})$ with $30 \mathrm{bp}$ inverted repeats (IRs) at both ends (GenBank accession no. AY455830).

The second ORF (3536-4441 bp) was the novel HLGR $a p h\left(2^{\prime \prime}\right)$ allele gene, aph $\left(2^{\prime \prime}\right)-I e$, encoding a gentamicinmodifying enzyme. The deduced amino acid sequence had $93.7 \%$ identity with the chromosome-encoded $\mathrm{APH}\left(2^{\prime \prime}\right)$-Id AMEs reported by Tai et al. (1998), with 19 amino acid differences. Also, its amino acid sequence was $29 \cdot 2,31 \cdot 1$ and $27 \cdot 8 \%$ identical with the phosphotransferases encoded by $a p h\left(2^{\prime \prime}\right)-I a$ (GenBank accession no. M13771), aph $\left(2^{\prime \prime}\right)-I b$ (GenBank accession no. AF207840) and aph $\left(2^{\prime \prime}\right)-I c$ (GenBank accession no. U51479), respectively.

The third ORF (7074-7982 bp) was the gene of a putative plasmid replication initiator protein (RepD) (GenBank accession no. X92946) which is involved in the introduction of a single-strand nick on the leading strand at the origin of replication and in the initiation of rolling-circle plasmid replication (Perreten et al., 2001).

The last ORF (7990-8724 bp) was the truncated streptomycin adenylyltransferase gene (str), interrupted by the internal HindIII site, so that only part of the gene was on the $\sim 8 \mathrm{~kb}$ fragment sequenced. The str gene belongs to the aminoglycoside adenylyltransferase (aad) family. Its amino acid sequence showed $100 \%$ identity with that of the recently detected plasmid-mediated streptomycin adenylyltransferase gene from isolates of Lactococcus lactis (GenBank accession no. X92946) (Schwarz et al., 2001; Projan et al., 1988). Its amino acid sequence was also $80 \cdot 3$ and $13 \cdot 9 \%$ identical to $6^{\prime}$ streptomycin adenylyltransferase ( $a a d E)$ and 3 "-streptomycin adenylyltransferase (aadA), respectively, from Enterococcus (GenBank accession nos AY602212 and AF052459) (Derbise et al., 1997; Ahmed \& Shimamoto, 2004; Clark et al., 1999).

\section{Identification of the $\operatorname{aph}\left(2^{\prime \prime}\right)-l e$ and str genes in enterococci}

Among 102 clinical enterococci, one Ent. faecium isolate (HZ438) and one Ent. gallinarum isolate (HZ472) with HLGR were confirmed to contain the $a p h\left(2^{\prime \prime}\right)$-Ie gene, and three Ent. faecalis isolates (HZ46, HZ57 and HZ179) and one Ent. faecium isolate (HZ438) had the str gene. This Ent. faecium isolate contained both $a p h\left(2^{\prime \prime}\right)-I e$ and str.

\section{DISCUSSION}

The $a a c\left(6^{\prime}\right)-I e-a p h\left(2^{\prime \prime}\right)-I a$ gene is the main AME gene associated with HLGR, encoding $\mathrm{AAC}\left(6^{\prime}\right)-\mathrm{Ie}-\mathrm{APH}\left(2^{\prime \prime}\right)$-Ia.
This bifunctional enzyme can cause the resistance of the enterococcus to essentially all clinically available aminoglycosides, except streptomycin, and eliminates the synergism between aminoglycosides and a cell-wall-active agent (Ferretti et al., 1986). The complete or truncated Tn5281 containing the $a a c\left(6^{\prime}\right)-I e-a p h\left(2^{\prime \prime}\right)-I a$ gene with IS256 upstream and/or downstream has been detected worldwide among strains displaying HLGR (Simjee et al., 1999; Hallgren et al., 2003). This is one explanation for the higher frequency of enterococci with HLGR. APH( $\left.2^{\prime \prime}\right)$-Ic, $\operatorname{APH}\left(2^{\prime \prime}\right)$-Id and $\operatorname{APH}\left(2^{\prime \prime}\right)$-Ib are comparatively rare in enterococci (Chow et al., 1997; Tai et al., 1998; Kao et al., 2000). The $\operatorname{aph}\left(2^{\prime \prime}\right)-I c$ gene is associated with gentamicin resistance (MIC 256-584 $\mathrm{g} \mathrm{ml}^{-1}$ ) and loss of synergism (Chow et al., 1997). The $a p h\left(2^{\prime \prime}\right)-I d$ and $a p h\left(2^{\prime \prime}\right)-I b$ genes result in high-level resistance to aminoglycosides, except streptomycin ( $\mathrm{MIC} \geqslant 2000 \mu \mathrm{g} \mathrm{ml}^{-1}$ ), but do not eliminate the synergism between amikacin and a cell-wall-active agent (Tai et al., 1998; Kao et al., 2000).

In this study, the AME APH( $\left.2^{\prime \prime}\right)$-Ie encoded by the novel HLGR $a p h\left(2^{\prime \prime}\right)$ allele $\left[a p h\left(2^{\prime \prime}\right)-I e\right]$ was detected, and differed from $\mathrm{APH}\left(2^{\prime \prime}\right)$-Id by a 19 aa substitution. The surrounding genetic structure of the $a p h\left(2^{\prime \prime}\right)-I e$ gene encoding this enzyme in Ent. casseliflavus HZ95 was determined in detail. The $a p h\left(2^{\prime \prime}\right)-I e$ gene was confirmed to reside on a $16 \mathrm{~kb}$ plasmid. By comparison of the MICs of aminoglycosides for E. coli pT95, containing the $a p h\left(2^{\prime \prime}\right)-I e$ gene, and E. coli pGEM-T Easy, it was shown that the MICs for gentamicin, netilmicin, tobramicin and kanamycin of E. coli pT95 were much higher than those of E. coli pGEM-T Easy. It may be concluded that the $a p h\left(2^{\prime \prime}\right)-I e$ gene can lead to resistance to gentamicin, netilmicin, tobramicin and kanamycin, but not to amikacin, isepamicin and streptomycin. The only functional difference between these genes is that the isolate from which $\operatorname{aph}\left(2^{\prime \prime}\right)$-Id was obtained had a lower level of resistance to netilmicin than Ent. casseliflavus containing the $a p h\left(2^{\prime \prime}\right)-I e$. We detected the aph $\left(2^{\prime \prime}\right)-I e$ gene not only in Ent. casseliflavus but also in Ent. faecium and Ent. gallinarum detected in screens at our hospital over the course of 1 year.

Downstream of the $a p h\left(2^{\prime \prime}\right)$-Ie gene, the presence of the str gene may be the explanation of the low-level streptomycin resistance $\left(\mathrm{MIC}=128 \mu \mathrm{g} \mathrm{ml}^{-1}\right)$. The str gene has been reported in L. lactis and was first detected in Enterococcus. We detected the str gene not only in Ent. casseliflavus but also in three Ent. faecalis isolates and one Ent. faecium isolate. The Ent. faecium isolate contained both aph $\left(2^{\prime \prime}\right)-I e$ and str genes.

An upstream ISEcp1-like element was detected with a 22 aa substitution in the transposase compared to that of ISEcp1. ISEcp 1 is commonly related to the transmission of resistance genes such as CTX-M-type $\beta$-lactamase genes, but has not been reported in Gram-positive bacteria (Poirel et al., 2005; Cao et al., 2002). Accordingly, we presume that ISEcp1 is relevant to the transmission of $a p h\left(2^{\prime \prime}\right)-I e$ and str. According to Donabedian et al. (2003), the $a p h\left(2^{\prime \prime}\right)-I d$ and $a p h\left(2^{\prime \prime}\right)-I b$ genes, which are rarely found in human isolates, are more 
prevalent in several food-producing animals, and are transmitted from food-producing animals to humans through the food supply, since gentamicin is commonly used in swine, and widely used in chickens and turkeys. It is presumed that these novel aminoglycoside-modifying genes and the IS in Enterococcus were acquired from the environment. The presence of these two linked aminoglycoside-resistance genes that might have been transferred from diverse bacterial species is another example of how bacteria evolve to become more resistant to a broader spectrum of antimicrobial agents.

\section{ACKNOWLEDGEMENTS}

We are grateful to Kristin Hegstad Dahl, PhD, University Hospital of North-Norway, for kindly providing the two recipient strains Ent. faecalis JH2-2 and Ent. faecium BM4105-RF. This work was supported in part by grant 011103717 from the Project Foundation of Zhejiang Science Department, China.

\section{REFERENCES}

Ahmed, A. M. \& Shimamoto, T. A. (2004). Plasmid-encoded class 1 integron carrying sat, a putative phosphoserine phosphatase gene and aadA2 from enterotoxigenic Escherichia coli $\mathrm{O} 159$ isolated in Japan. FEMS Microbiol Lett 235, 243-248.

Cao, V., Lambert, T. \& Courvalin, P. (2002). ColE1-like plasmid pIP843 of Klebsiella pneumoniae encoding extended-spectrum betalactamase CTX-M-17. Antimicrob Agents Chemother 46, 1212-1217.

Chow, J. W., Zervos, M. J., Lerner, S. A., Thal, L. A., Donabedian, S. M., Jaworski, D. D., Tsai, S., Shaw, K. J. \& Clewell, D. B. (1997). A novel gentamicin resistance gene in Enterococcus. Antimicrob Agents Chemother 41, 511-514.

Clark, N. C., Olsvik, O., Swenson, J. M., Spiegel, C. A. \& Tenover, F. C. (1999). Detection of a streptomycin/spectinomycin adenylyltransferase gene (aadA) in Enterococcus faecalis. Antimicrob Agents Chemother 43, 157-160.

CLSI (2005). Methods for Dilution Antimicrobial Susceptibility Tests for Bacteria that Grow Aerobically; Approved Standard. CLSI document M7A6, 6th edn. Wayne, PA: Clinical and Laboratory Standards Institute.

Derbise, A., Aubert, S. \& Solh, N. E. (1997). Mapping the regions carrying three contiguous antibiotic resistance genes aadE, sat4, and aphA-3 in the genomes of staphylococci. Antimicrob Agents Chemother 41, 1024-1032.

Donabedian, S. M., Thal, L. A., Hershberger, E. \& 13 other authors (2003). Molecular characterization of gentamicin-resistant enterococci in the United States: Evidence of spread from animals to humans through food. J Clin Microbiol 41, 1109-1113.

Eliopoulos, G. M., Farber, B. F., Murray, B. E., Wennersten, C. \& Moellering, R. C. (1984). Ribosomal resistance of clinical enterococcal isolates to streptomycin. Antimicrob Agents Chemother 25, 398-399.
Ferretti, J. J., Gilmore, K. S. \& Courvalin, P. (1986). Nucleotide sequence analysis of the gene specifying the bifunctional $6^{\prime}$ aminoglycoside acetyltransferase enzyme in Streptococcus faecalis and identification and cloning of gene regions specifying the two activities. J Bacteriol 167, 631-638.

Hallgren, A., Saeedi, B., Nilsson, M., Monstein, H. J., Isaksson, B., Hanberger, H. \& Nilsson, L. E. (2003). Genetic relatedness among Enterococcus faecalis with transposon-mediated high-level gentamicin resistance in Swedish intensive care units. J Antimicrob Chemother 52, 162-167.

Ike, Y., Tanimoto, K., Tomita, H., Takeuchi, K. \& Fujimoto, S. (1998). Efficient transfer of the pheromone-independent Enterococcus faecium plasmid pMG1 (Gmr) $(65 \cdot 1$ kilobases) to Enterococcus strains during broth mating. J Bacteriol 180, 4886-4892.

Kao, S. J., You, I., Clewell, D. B., Donabedian, S. M., Zervos, M. J., Petrin, J., Shaw, K. J. \& Chowl, J. W. (2000). Detection of the highlevel aminoglycoside resistance gene $a p h\left(2^{\prime \prime}\right)-I b$ in Enterococcus faecium. Antimicrob Agents Chemother 44, 2876-2879.

Murray, B. E. (1998). Diversity among multidrug-resistant enterococci. Emerg Infect Dis 4, 37-47.

Perreten, V., Schwarz, F. V., Teuber, M. \& Levy, S. B. (2001). Mdt(A), a new efflux protein conferring multiple antibiotic resistance in Lactococcus lactis and Escherichia coli. Antimicrob Agents Chemother 45, 1109-1114.

Poirel, L., Lartigue, M. F., Decousser, J. W. \& Nordmann, P. (2005). ISEcp1B-mediated transposition of bla $a_{\mathrm{CTX}-\mathrm{M}}$ in Escherichia coli. Antimicrob Agents Chemother 49, 447-450.

Projan, S. J., Moghazeh, S. \& Novick, R. P. (1988). Nucleotide sequence of pS194, a streptomycin-resistance plasmid from Staphylococcus aureus. Nucleic Acids Res 16, 2179-2187.

Schaberg, D. R., Culver, D. H. \& Gaynes, R. P. (1991). Major trends in the microbial etiology of nosocomial infection. Am J Med 91 (Suppl. 3B), 72S-75S.

Schwarz, F. V., Perreten, V. \& Teuber, M. (2001). Sequence of the $50-\mathrm{kb}$ conjugative multiresistance plasmid pRE25 from Enterococcus faecalis RE25. Plasmid 46, 170-187.

Simjee, S., Fraise, A. P. \& Gill, M. J. (1999). Plasmid heterogeneity and identification of a Tn5281-like element in clinical isolates of high-level gentamicin-resistant Enterococcus faecium isolated in the UK. J Antimicrob Chemother 43, 625-635.

Tai, S. F., Zervos, M. J., Clewell, D. B., Donabedian, S. M., Sahm, D. F. \& Chow, J. W. (1998). A new high-level gentamicin resistance gene, aph $\left(2^{\prime \prime}\right)-I d$, in Enterococcus spp. Antimicrob Agents Chemother 42, 1229-1232.

Wang, Q., Xu, Y. C., Wang, H., Chen, M. J., Zhang, X. Z., Xu, S. Z. \& Wu, J. (1999). Antimicrobial resistant characteristics in enterococci and antibiotics for enterococcal infections. Chinese Journal of Laboratory Medicine 22, 154-156 (in Chinese).

Werner, G., Hildebrandt, B. \& Witte, W. (2001). Aminoglycosidestreptothricin resistance gene cluster aadE-sat4-aphA-3 disseminated among multiresistant isolates of Enterococcus faecium. Antimicrob Agents Chemother 45, 3267-3269. 